\title{
SORPTION AND SEPARATION OF PALLADIUM, PLATINUM AND GOLD CHLOROCOMPLEXES BY MEANS OF A DIPICOLINIC ACID POLYSTYRENE-BASED CHELATING RESIN
}

\author{
GAVINO CHESSA, GLAMPAOLO MARANGONI, BRUNO PITTERI * , NICOLETTA STEVANATO \\ and ANDREA VAVASORI
}

Dipartimento di Chimica, Università di Venezia, Calle Larga S. Marta, 2137, Venezia (Italy)

(Received June 13, 1990; accepted in revised form October 13, 1990)

\begin{abstract}
A chelating ion-exchange resin containing dipicolinic acid as functional group and based on microporous chloromethylated cross-linked polystyrene-divinylbenzene (2\%) copolymer has been prepared. Its sorption and desorption characteristics for $P d(I I), P t(I I), P t(I V)$ and $A u(I I I)$ have been studied in aqueous chloride solutions under a number of experimental conditions, both in batch and in column, at room temperature and constant ionic strength $(\mu=1 \mathrm{~mol} / \mathrm{l}, \mathrm{KCl} / \mathrm{HCl})$. In column operations at $\mathrm{pH} 6, \mathrm{Pd}(\mathrm{II})$ can be separated from $P t(I I)$ or $P t(I V)$ owing to the different rate of formation of the immobilized chelated species, From a mixture of $P d(I I), P t(I V)$ and $A u(I I I)$ at $p H 6, P t(I V)$ flows unaffected, whereas $A u(I I I)$ and $P d(I I)$ are both retained and successively separated by selective elution. From the same mixture at $p H \leqslant 0$ only $A u(I I I)$ is sorbed by anionic exchange.
\end{abstract}

\section{INTRODUCTION}

Selective complexation for separation and recovery of metal ions, expecially from dilute aqueous solutions, is the main object of chelating resins. For this purpose a large number of different chelating ligands have been incorporated into polymer matrices, with preference for the polystyrene-based polymers $[1,2]$, as these are chemically stable under the conditions of use. The hydrophobic character of the polystyrene backbone which affects unfavourably the access of metal ions to the chelating groups in the resin has been partially overcome by introducing into the polymer network hydrophilic ligands. One of the most extensively studied ion-exchange chelating resins is that containing iminodiacetic acid (IDA) groups. This resin, commercially available under different trade names, has been found suitable for separation and preconcentration of metal ions [3] and, in particular, it is effective in sequestering $\mathrm{Fe}$ (III) [4]. Following the success of this resin a wide

0923-1137/91/\$03.50 1991 - Elsevier Science Publishers B.V. 
variety of ion-exchangers containing ligands similar to iminodiacetic acid have been prepared and studied [2].

Recently it has been found that 2,6pyridinedicarboxylic acid (L), an analogue of IDA, reacts in aqueous solution at very different rates with $\mathrm{PtCl}_{4}^{2-}$ and $\mathrm{PdCl}_{4}^{2-}$ anions to give mono-anionic $[\mathrm{Me}(\mathrm{L}-2 \mathrm{H}) \mathrm{Cl}]^{-}(\mathrm{Me}=$ $\mathrm{Pt}, \mathrm{Pd})$ and neutral $\left[\mathrm{Me}(\mathrm{L}-\mathrm{H})_{2}\right](\mathrm{Me}=\mathrm{Pt}, \mathrm{Pd})$ square planar tetracoordinate compounds, which have been separated in the solid state and characterized [5-7]. In addition, fast coordinative interaction has been observed spectrophotometrically by reaction of $\mathrm{AuCl}_{4}^{-}$ with L, even if no solid product has been isolated. On the other hand, no reaction has been observed with $\mathrm{PtCl}_{6}^{2-}$. Based on these features, it was then expected that a resin containing dipicolinic acid groups would be suitable to separate the above mentioned metal ions. In the present paper the preparation and the sorption behaviour of a dipicolinic acid polystyrene-based chelating resin towards $\mathrm{Pd}(\mathrm{II}), \mathrm{Pt}(\mathrm{II}), \mathrm{Pt}(\mathrm{IV})$ and $\mathrm{Au}(\mathrm{III})$ chloro-anions, both in batch conditions and in column, as well as the recovery of the sorbed metal ions, are reported.

\section{EXPERIMENTAL}

\section{Materials and methods}

Unless specified, all solvents and reagents (Aldrich and Fluka) were used without further purification. Crystalline $\mathrm{K}\left[\mathrm{AuCl}_{4}\right]$. $2 \mathrm{H}_{2} \mathrm{O}, \mathrm{K}_{2}\left[\mathrm{PtCl}_{4}\right], \mathrm{K}_{2}\left[\mathrm{PtCl}_{6}\right]$ and $\mathrm{K}_{2}\left[\mathrm{PdCl}_{4}\right]$ were prepared from high purity metals by standard methods. Microporous chloromethylpolystyrene cross-linked with $2 \%$ DVB (200-400 mesh, $2.3 \mathrm{meq} \mathrm{Cl} / \mathrm{g}$, surface area $44.25 \pm 0.01 \mathrm{~m}^{2} / \mathrm{g}$ ) was purchased from Fluka.

I.R. spectra were recorded on a PerkinElmer 683 or on a Bio-Rad Digilab FTS-40 spectrophotometer. U.V. spectra were taken on a Perkin-Elmer Lambda 5 spectrophotometer using matched $1 \mathrm{~cm}$ quartz cells. Metal ion concentrations were measured with a Perkin-Elmer 2380 atomic absorption spectrophotometer. Elemental analysis were performed by the Microanalytical Laboratory of the University of Padua. Surface area (B.E.T.) was determined with a Carlo Erba Sorptomatic 1800 instrument.

\section{Synthesis of the resin}

2,6-Dimethoxycarbonyl-4-hydroxypyridine (1) and $[(2,6$-dicarboxymethyl-4-pyridyl)oxymethyllpolystyrene (2)

Compounds (1) and (2) were prepared according to the published procedure [8]. Analysis for 2: calc. (\%) for $\left(\mathrm{C}_{10} \mathrm{H}_{10}\right)_{0.02}$ $\left(\mathrm{C}_{8} \mathrm{H}_{8}\right)_{0.71}\left(\mathrm{C}_{18} \mathrm{H}_{17} \mathrm{NO}_{5}\right)_{0.27}: \mathrm{C}, 78.2 ; \mathrm{H}, 6.4$; $\mathrm{N}, 2.3$. Found: C, $78.0 ; \mathrm{H}, 6.2 ; \mathrm{N}, 2.3$.

Potassium [(2,6-dicarboxylate-4-pyridyl)oxymethyl]polystyrene (3)

A suspension of (2) (18.5 g, $30.34 \mathrm{meq}$ of nitrogen) in $450 \mathrm{ml}$ of 1,2-dichloroethane was treated with $150 \mathrm{ml}$ of an aqueous solution of $50 \% \mathrm{KOH}$ containing Adogen $464(5 \mathrm{~g})$, and the resulting mixture was allowed to react for $48 \mathrm{~h}$ at $70^{\circ} \mathrm{C}$ under stirring and an atmosphere of nitrogen. After cooling the solid was filtered off, washed exhaustively with $\mathrm{H}_{2} \mathrm{O}$, $\mathrm{MeOH}, \mathrm{H}_{2} \mathrm{O}$, THF $/ \mathrm{H}_{2} \mathrm{O}(3: 1, \mathrm{v} / \mathrm{v})$, THF, acetone, dichloromethane and finally with $\mathrm{H}_{2} \mathrm{O}$ to neutral $\mathrm{pH}$. The resin was then dried under vacuum for $24 \mathrm{~h}$ at $50^{\circ} \mathrm{C}$. I.R. ( $\mathrm{KBr}$ pellets): $1620 \mathrm{~cm}^{-1}\left[\mathrm{~s}, \mathrm{~b} ; \nu\left(\mathrm{COO}^{-}\right)\right]$. Analysis: calc. (\%) for $\left(\mathrm{C}_{10} \mathrm{H}_{10}\right)_{0.02}\left(\mathrm{C}_{8} \mathrm{H}_{8}\right)_{0.71}\left(\mathrm{C}_{16}\right.$ $\left.\mathrm{H}_{11} \mathrm{NO}_{5} \mathrm{~K}_{2}\right)_{0.27}: \mathrm{C}, 69.0 ; \mathrm{H}, 5.0 ; \mathrm{N}, 2.1$. Found: C, 68.5; H, 5.5; N, 2.1 .

\section{Stability}

In order to estimate the stability of the resin in acid solutions, four portions of the resin $(100 \mathrm{mg})$ where shaken with $10 \mathrm{ml}$ of $\mathrm{HCl} 0.1 M, 1 M, 2 M$ and $12 M$, respectively, 
for 7 days. The content of released chelidamic acid was determined spectrophotometrically by comparision with the spectra of solutions of chelidammic acid under the same acidity conditions.

\section{Analysis}

Atomic absorption spectrophotometry was used for analysis of metal ions in solution. The extent of sorption of metal ions was calculated from the difference of metal concentrations in the substrate before and after sorption by the resin and/or in the solutions after stripping or elution with $2 \mathrm{M} \mathrm{HCl}$ or 1 $M \mathrm{KCN}$.

\section{Sorption experiments}

A batch technique was used to study metal ions uptake as a function of $\mathrm{pH}$, sorption rate behaviour and sorption isotherms. Measured amounts of the resin, equilibrated in $25 \mathrm{ml}$ aqueous solutions at the desidered $\mathrm{pH}$ values, were vigorously shaken with $25 \mathrm{ml}$ aqueous solutions of known concentrations of $\mathrm{K}\left[\mathrm{AuCl}_{4}\right] \cdot 2 \mathrm{H}_{2} \mathrm{O}, \mathrm{K}_{2}\left[\mathrm{PtCl}_{4}\right], \mathrm{K}_{2}\left[\mathrm{PtCl}_{6}\right]$, and $\mathrm{K}_{2}\left[\mathrm{PdCl}_{4}\right]$, at the same $\mathrm{pH}$ values in tightly stoppered flasks for $48 \mathrm{~h}$ at $25^{\circ} \mathrm{C}$, using an oscillatory shaker with $3 \mathrm{~cm}$ stroke at 80 cyclings $\min ^{-1}$. The equilibrium sorption was calculated from the residual metal concentration of the sorbate in the equilibrated solution or after stripping of the metal ion. All the experiments were made at constant ionic strength $(\mu=1 \mathrm{~mol} / \mathrm{l}, \mathrm{KCl} / \mathrm{HCl})$, which also prevents the formation of solvolyzed species of $\mathrm{Pd}(\mathrm{II})$ and $\mathrm{Au}(\mathrm{III})$. Separations of mixtures of metal ions were performed in small glass columns $(25 \mathrm{~cm}$ length, $0.6 \mathrm{~cm}$ inside diameter). Resin ( $1 \mathrm{~g}$ ) was packed into the column and equilibrated with aqueous solutions $(\mu=1 \mathrm{~mol} / 1, \mathrm{KCl} / \mathrm{HCl})$ at fixed working $\mathrm{pH}$ values. Metal solutions (10 or $20 \mathrm{ml}$ ) were percolated through the column at a rate of $8 \mathrm{ml} \mathrm{h}^{-1}$. Both effluents and eluates with
$\mathrm{HCl} 2 M$ or $\mathrm{KCN} 1 M$ were collected and diluted to $25 \mathrm{ml}$ in volumetric flasks and analyzed by atomic absorption spectrophotometry.

\section{RESULTS AND DISCUSSION}

\section{Synthesis and characterization of the resin}

The synthesis of the resin is summarized in Scheme 1. The reaction of 2,6-dimethoxycarbonyl-4-hydroxypyridine (1) with chloromethylpolystyrene, in the presence of $\mathrm{Cs}_{2} \mathrm{CO}_{3}$ provided resin (2) from which resin (3) was obtained by base hydrolysis under phasetransfer catalyzed conditions with $100 \%$ conversion, corresponding to a loading of 1.49 mmol ligand per gram of dry resin in the potassium form. The infrared spectrum of (3) shows two bands at 1620 and $1405 \mathrm{~cm}^{-1}$ for the asymmetric and symmetric stretching vibrations of the carboxylate anions, respectively. Whereas it does not exhibit any band at $1725 \mathrm{~cm}^{-1}$ for the ester precursor (2). The resin in the potassium form can be converted to the acid form by equilibration with $\mathrm{HCl} 2$ $M$; in this form the infrared spectrum shows a broad band centered at $1740 \mathrm{~cm}^{-1}$ due to the stretching vibration of the carboxylic groups while the carboxylate bands at 1620 and $1405 \mathrm{~cm}^{-1}$ have disappeared. The resin proved to be stable in $2 \mathrm{M} \mathrm{HCl}$, whereas a release of chelidamic acid corresponding to $2 \%$ of that theoretically bound to the resin was detected after seven days of contact with concentrated $\mathrm{HCl}$.

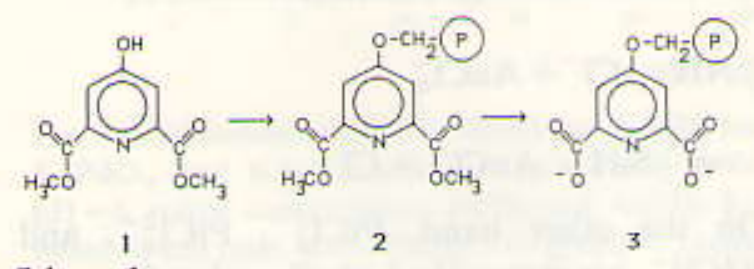

Scheme 1 


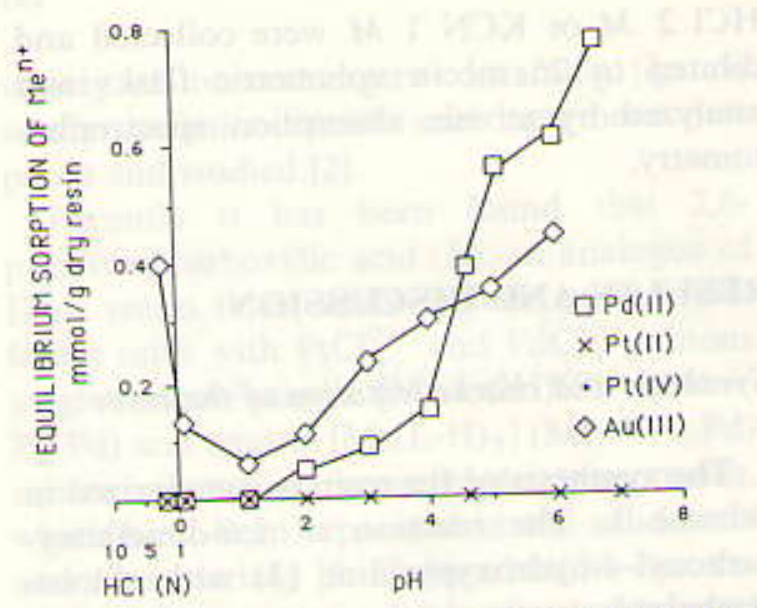

Fig. 1. Effect of $\mathrm{pH}$ on equilibrium sorption of $\mathrm{Me}^{n+}$ Initial concentration of solutions, $4 \mathrm{mmol} / 1 \mathrm{Me}^{n+}$ as chloro anions; resin charge $2.89 \mathrm{~g}$ (wet)/1; temperature $25^{\circ} \mathrm{C}$.

\section{Batch experiments}

\section{Effect of $\mathrm{pH}$ on sorption}

The sorption behaviour of the resin toward $\mathrm{AuCl}_{4}^{-}, \mathrm{PtCl}_{4}^{2-}, \mathrm{PtCl}_{6}^{2-}$ and $\mathrm{PdCl}_{4}^{2-}$ was investigated in aqueous solutions in the $\mathrm{pH}$ range $0-7(\mu=1 \mathrm{~mol} / 1, \mathrm{KCl} / \mathrm{HCl})$ and in 2 $N \mathrm{HCl}$. The $\mathrm{pH}$ profiles of the equilibrium sorption are shown in Fig. 1. $\mathrm{Pt}(\mathrm{II})$ and $\mathrm{Pt}(\mathrm{IV})$ are not sorbed at any examined $\mathrm{pH}$, whereas sorption capacities for $\mathrm{Au}(\mathrm{III})$ and $\mathrm{Pd}(\mathrm{II})$ are maximal at $\mathrm{pH} 6$ and $\mathrm{pH} 6.5$, respectively, and decrease continuously to $\mathrm{pH} 1.1$. Sorption experiments at higher $\mathrm{pH}$ are not possible due either to reduction to metallic gold or precipitation of hydroxo species of palladium(II) for $\mathrm{pH}$ values above 6 and 6.5 , respectively. The $\mathrm{AuCl}_{4}^{-}$sorption capacity of the resin, however, increases again at $\mathrm{pH}<1.1$ in $\mathrm{HCl}$ media and this may be attributed to the anion exchange reaction

$$
\begin{aligned}
& >\stackrel{+}{\mathrm{N}} \mathrm{H} \ldots \mathrm{Cl}^{-}+\mathrm{AuCl}_{4}^{-} \\
& \rightleftharpoons \stackrel{+}{\mathrm{N}} \mathrm{H} \ldots . \mathrm{AuCl}_{4}^{-}+\mathrm{Cl}^{-}
\end{aligned}
$$

On the other hand, $\mathrm{PtCl}_{4}^{2-}, \mathrm{PtCl}_{6}^{2-}$, and $\mathrm{PdCl}_{4}^{2-}$ are not sorbed at all under the same experimental conditions and this may be ascribed to competition of the chloride ion with the resin ligand. These results agree with previous findings on chloro complexes of gold and platinum metals which clearly indicate that the strength of electrostatic interaction is highly dependent on the charge of the complex and the preference in anion exchange for large singly charged anions [9]. $\mathrm{PdCl}_{4}^{2-}$ is likely to be sorbed by the resin at $\mathrm{pH}$ 6-6.5 through chelation, according to the following reaction:

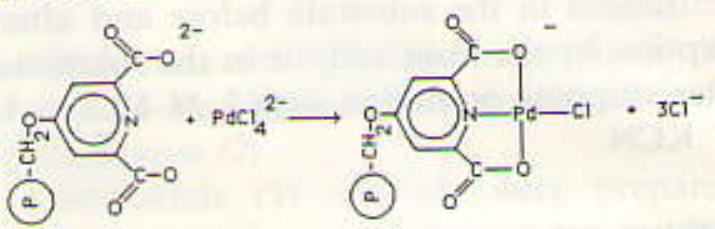

as deduced by comparing the I.R. spectrum of the resin saturated with $\mathrm{PdCl}_{4}^{2-}$ at $\mathrm{pH} 6$ with that of a sample of $\mathrm{K}[\mathrm{Pd}(\mathrm{L}-2 \mathrm{H}) \mathrm{Cl}]$ prepared independently [7]. The former showed two bands centered at 1665 and $308 \mathrm{~cm}^{-1}$, whereas the latter two bands at 1670 and 308 $\mathrm{cm}^{-1}$, which can be assigned to the coordinated $-\mathrm{COO}$ and $\mathrm{Pd}-\mathrm{Cl}$ stretching vibrations, respectively.

The I.R. spectrum of the resin saturated with $\mathrm{AuCl}_{4}^{-}$at pH 6 exhibited three significant relatively broad bands centered at 1715 , 1615 and $355 \mathrm{~cm}^{-1}$, not present in the spectrum of the chelating resin. The bands at 1715 and $355 \mathrm{~cm}^{-1}$ can reasonably be assigned to coordinated $-\mathrm{COO}$ and $\mathrm{Au}-\mathrm{Cl}$ stretching vibrations, respectively, on the basis of assignments made on the correlated complex $\left[\mathrm{Au}\right.$ (pic) $\mathrm{Cl}_{2}$ ] [10] (pic $=2$-pyridinecarboxylato), in which case coordinated - $\mathrm{COO}$ and $\mathrm{Au}-\mathrm{Cl}$ stretching vibrations occurred at 1705 and $380 \mathrm{~cm}^{-1}$. The third band in the spectrum of the resin at $1615 \mathrm{~cm}^{-1}$ is likely to be due to the asymmetric stretching of free carboxylate anion $-\mathrm{COO}^{-}$. These features suggest that at pH 6 the dipicolinate behaves as a bidentate ligand towards $\mathrm{Au}(\mathrm{III})$, giving 


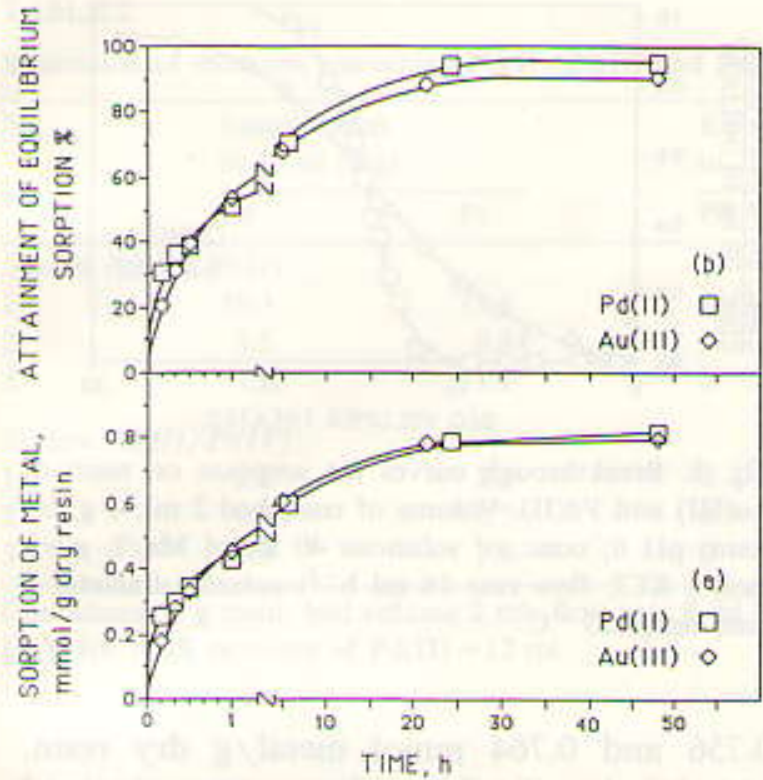

Fig. 2. (a) Rate of sorption by resin of $\mathrm{Pd}(\mathrm{II})$ and $\mathrm{Au}(\mathrm{III})$ from $\mathrm{K}_{2} \mathrm{PdCl}_{4}$ and $\mathrm{KAuCl}_{4}$ solutions $(\mu=1$ $\mathrm{mol} / 1, \mathrm{KCl}, \mathrm{pH} 6$, initial concentration $40 \mathrm{mmol} / \mathrm{l}$ ). (b) Rate of attainment of equilibrium sorption. Resin charge $2.89 \mathrm{~g}$ (wet) $/ 1$; temperature $25^{\circ} \mathrm{C}$.

rise to immobilized tetracoordinated dichloro species. The 1.R. spectrum of the resin loaded with $\mathrm{Au}(\mathrm{III})$ in $2 \mathrm{M} \mathrm{HCl}$ showed in the same region only the band at $1740 \mathrm{~cm}^{-1}$ characteristic of free carboxylic groups not involved in chelation.

\section{Kinetic behaviour}

The kinetic behaviour of the resin towards $\mathrm{PdCl}_{4}^{2-}$ and $\mathrm{AuCl}_{4}^{-}$was studied at $\mathrm{pH} 6$ under vigorous agitation at room temperature. In order to obtain the rate of fractional attainment of equilibrium sorption as a function of time, the data were divided by the corresponding sorption values measured at equilibrium. The results plotted in Fig. 2 show that the resin has relatively slow sorption kinetics either for $\mathrm{PdCl}_{4}^{2-}$ or $\mathrm{AuCl}_{4}^{-}$, the $50 \%$ of the equilibrium sorption $\left(t_{1 / 2}\right)$ being reached in about 60 minutes. This is consistent with the low surface area $\left(44.25 \pm 0.01 \mathrm{~m}^{2} / \mathrm{g}\right)$ and the styrenic character of the resin, due to the rather low functionalization level given that the original chloromethyl capacity is only $2.3 \mathrm{mmol} \mathrm{g}^{-1}$. The ability of the resin to function in ion exchange is therefore due to the presence of ionized groups $[11,12]$ which allow the swelling in aqueous solutions. In the potassium form the resin has a water regain [13] of $0.51 \mathrm{~g} \mathrm{~g} \mathrm{~g}^{-1}$, consistent with the measured $t_{1 / 2}$ and comparable with values reported in the literature for other polystyrene resins [13].

\section{Sorption isotherm for $P d(I I)$ and $A u(I I I)$}

The sorption capacity of the resin for $\mathrm{Pd}(\mathrm{II})$ and $\mathrm{Au}(\mathrm{III})$ chloride anions as a function of metal ion concentration was examined at $\mathrm{pH}$ 6. The equilibrium sorption data are plotted in Fig. 3. Data treatment revealed that sorption conformed to Langmuir isotherm equation:

$\chi=10^{-3} K_{\mathrm{b}} A_{\mathrm{s}} C_{\mathrm{A}} /\left(1+10^{-3} K_{\mathrm{b}} C_{\mathrm{A}}\right)$

where $\chi$ is the equilibrium sorption ( $\mathrm{mmol}$ $\mathrm{Me} / \mathrm{g}$ dry resin), $C_{\mathrm{A}}$ is the equilibrium sorbate concentration (mmol Me/1), $A_{\mathrm{s}}$ is the saturation capacity (mmol Me $/ \mathrm{g}$ dry resin), and $K_{\mathrm{b}}$ is the binding constant $(1 / \mathrm{mol})$. The values of Langmuir isotherm parameters $\left(A_{\mathrm{s}}\right.$ and $\left.K_{\mathrm{b}}\right)$ were determined by least-squares fit (Fig. 4)

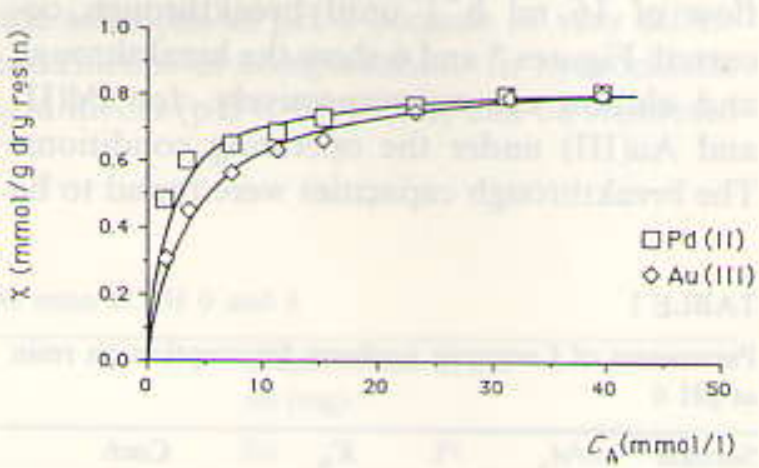

Fig. 3. Equilibrium sorption of $\mathrm{Pd}(\mathrm{II})$ and $\mathrm{Au}(\mathrm{III})$ from $\mathrm{K}_{2} \mathrm{PdCl}_{4}$ and $\mathrm{KAuCl}_{4}$ solutions $(\mu=1 \mathrm{~mol} / 1, \mathrm{KCl}$, $\mathrm{pH}=6$, initial concentration $\mathrm{Pd}(\mathrm{II})$ and $\mathrm{Au}(\mathrm{III}) 2-40$ $\mathrm{mmol} / \mathrm{l})$ and resin. Resin charge $2.89 \mathrm{~g}$ (wet)/1. Temperature $25^{\circ} \mathrm{C}$ 


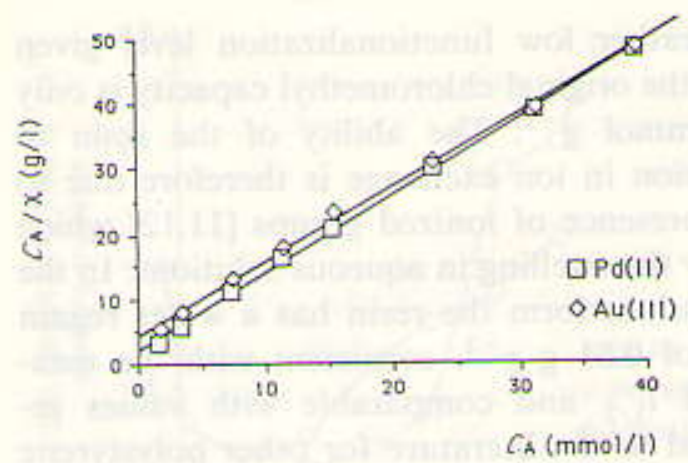

Fig. 4. Linearization of equilibrium sorption curves of Fig. 3.

plotting $C_{\mathrm{A}} / \chi$ versus $C_{\mathrm{A}}$. The results are given in Table 1 . The values of the binding constant $K_{\mathrm{b}}$ in eqn. (1) for $\mathrm{Pd}(\mathrm{II})(548 \mathrm{1} / \mathrm{mol})$ and $\mathrm{Au}$ (III) $(245 \mathrm{l} / \mathrm{mol})$ account for the weaker dependence of sorption capacity of $\mathrm{Pd}(\mathrm{II})$ than $\mathrm{Au}(\mathrm{III})$ on the solution concentration.

\section{Column separation experiments}

The possibility to use the resin for selective column separation of the metal ions examined was investigated by column tests. In order to determine the column capacities at $\mathrm{pH} 6$ and stripping conditions for $\mathrm{Pd}(\mathrm{II})$ and $\mathrm{Au}(\mathrm{III})$, breakthrough and elution studies were carried out on a $1 \mathrm{~g}$ resin column $(2 \mathrm{ml}$ bed volume). A $40 \mathrm{mmol} / 1$ solution of metal ion was passed through the column resin at a flow of $16 \mathrm{ml} \mathrm{h}^{-1}$ until breakthrough occurred. Figures 5 and 6 show the breakthrough and elution curves, respectively, for $\mathrm{Pd}(\mathrm{II})$ and $\mathrm{Au}(\mathrm{III})$ under the operating conditions. The breakthrough capacities were found to be

\section{TABLE 1}

Parameters of Langmuir isotherm for sorption on resin at $\mathrm{pH} 6$

\begin{tabular}{llll}
\hline Sorbate & $\begin{array}{l}A_{\mathrm{s}} \\
\text { (mmol/g } \\
\text { dry resin) }\end{array}$ & $\begin{array}{l}K_{\mathrm{b}} \\
(\mathrm{l} / \mathrm{mol})\end{array}$ & $\begin{array}{l}\text { Corr. } \\
\text { coeff. }\end{array}$ \\
\hline $\mathrm{PdCl}_{4}^{2-}$ & 0.840 & 548 & 0.999 \\
$\mathrm{AuCl}_{4}^{-}$ & 0.888 & 245 & 0.998 \\
\hline
\end{tabular}

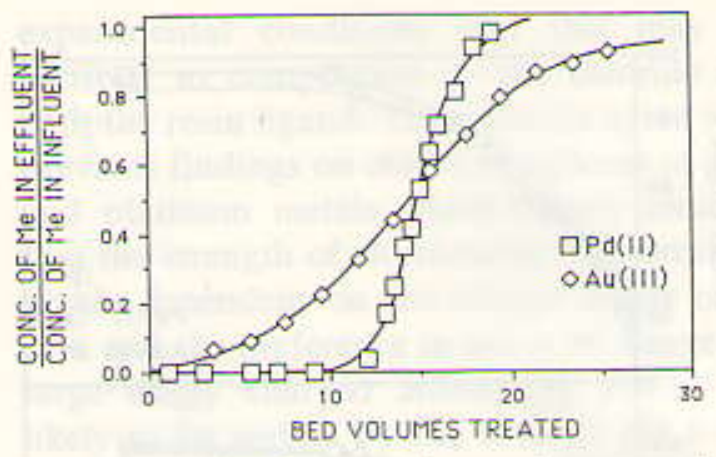

Fig. 5. Breakthrough curves for sorption on resin of $\mathrm{Au}(\mathrm{III})$ and $\mathrm{Pd}(\mathrm{II})$. Volume of resin bed $2 \mathrm{ml} ; 1 \mathrm{~g}$ dry resin; $\mathrm{pH} 6$; conc. of solutions $40 \mathrm{mmol} \mathrm{Me} / \mathrm{l} ; \mu=1$ $\mathrm{mol} / 1, \mathrm{KCl}$; flow rate $16 \mathrm{ml} \mathrm{h}^{-1}$; column diameter 6 $\mathrm{mm}$; temp. $25^{\circ} \mathrm{C}$.

0.756 and $0.764 \mathrm{mmol}$ metal $/ \mathrm{g}$ dry resin, respectively. Similar values were obtained from equilibrium sorption measurements. This suggests a high utilization of the column capacity.

The results summarized in Table 2 indicate that when $\mathrm{Pd}(\mathrm{II})-\mathrm{Pt}(\mathrm{II})$ or $\mathrm{Pd}(\mathrm{II})-\mathrm{Pt}(\mathrm{IV})$ mixtures of varying molar ratios were passed through a column of the resin at $\mathrm{pH} 6, \mathrm{Pd}$ (II) can be succesfully separated from $\mathrm{Pt}(\mathrm{II})$ or $\mathrm{Pt}$ (IV). In every separation $\mathrm{Pd}(\mathrm{II})$ was completely sorbed while $\mathrm{Pt}(\mathrm{II})$ or $\mathrm{Pt}$ (IV) were not retained at all. A $100 \%$ recovery of the $\mathrm{Pd}(\mathrm{II})$ retained on the column could be achieved by

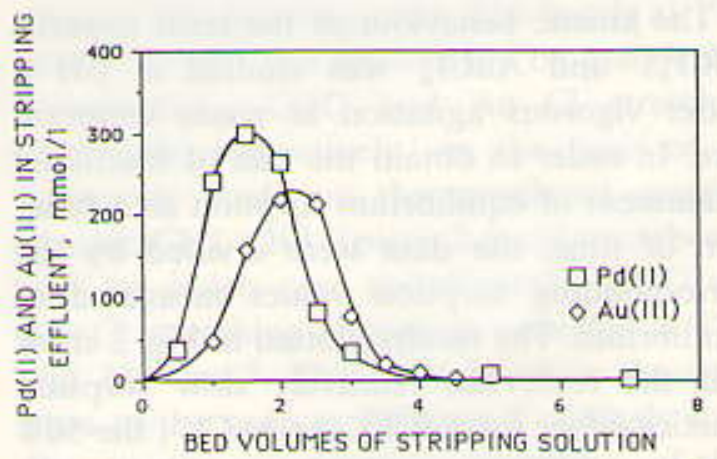

Fig. 6. Stripping of resin columns (bed volume $2 \mathrm{ml}$ ) loaded with $\mathrm{Pd}$ (II) and $\mathrm{Au}(\mathrm{III})$ (0.756 and 0.764 $\mathrm{mmol} / \mathrm{g}$, respectively). Flow rate of stripping solutions (2 $N \mathrm{HCl}$ for $\mathrm{Pd}$ and $1 M \mathrm{KCN}$ for $\mathrm{Au}$ ): $16 \mathrm{ml} \mathrm{h}^{-1}$. 
TABLE 2

Separation of mixtures containing $\mathrm{Pd}(\mathrm{II}) / \mathrm{Pt}(\mathrm{II})$ and $\mathrm{Pd}(\mathrm{II}) / \mathrm{Pt}(\mathrm{IV})$ by the resin at $\mathrm{pH} 6$

\begin{tabular}{|c|c|c|c|c|c|c|}
\hline \multirow[t]{2}{*}{ No. } & \multicolumn{2}{|c|}{$\begin{array}{l}\text { Initial concn. } \\
\text { in } 10 \mathrm{ml}(\mathrm{mg})\end{array}$} & \multicolumn{2}{|c|}{$\begin{array}{l}\text { Effluent concn. } \\
\text { in } 25 \mathrm{ml}(\mathrm{mg})\end{array}$} & \multicolumn{2}{|c|}{$\begin{array}{l}\text { Eluate concn. } \\
\text { in } 25 \mathrm{ml} 2 \mathrm{M} \mathrm{HCl}(\mathrm{mg})\end{array}$} \\
\hline & $\mathrm{Pd}$ & $\mathrm{Pt}$ & $\mathrm{Pd}$ & $\mathrm{Pt}$ & $\mathrm{Pd}$ & $\mathrm{Pt}$ \\
\hline \multicolumn{7}{|c|}{ System Pd(II)/Pt(II) } \\
\hline 1 & 10.3 & 11.8 & 0 & 11.8 & 10.3 & 0 \\
\hline 2 & 1.1 & 0.84 & 0 & 0.84 & 1.05 & 0 \\
\hline 3 & 1.1 & 31.2 & 0 & 31.2 & 1.05 & 0 \\
\hline \multicolumn{7}{|c|}{ System $P d(I I) / P t(I V)$} \\
\hline 1 & 2.1 & 1.5 & 0 & 1.5 & 2.1 & 0 \\
\hline 2 & 0.23 & 1.7 & 0 & 1.7 & 0.23 & 0 \\
\hline 3 & 22.3 & 1.8 & 0 & 1.8 & 22.3 & 0 \\
\hline
\end{tabular}

Conditions: $1 \mathrm{~g}$ resin, bed volume $2 \mathrm{ml}$; flow rate $8 \mathrm{ml} \mathrm{h}^{-1} ; \mu=1 \mathrm{~mol} / \mathrm{I} \mathrm{KCl}$ (initial solutions); eluent volume $(2 \mathrm{M}$ $\mathrm{HCl}$ ) for $100 \%$ recovery of $\mathrm{Pd}(\mathrm{II})=12 \mathrm{ml}$.

eluting with $12 \mathrm{ml}$ ( 6 bed volumes) of $2 M$ $\mathrm{HCl}$.

As shown in Table 3, separation of Au(III) from $\mathrm{Pd}(\mathrm{II})$ and $\mathrm{Pt}(\mathrm{IV})$ is also possible. To accomphish this separation a solution at $\mathrm{pH} 0$ containing a mixture of the three metal chloride anions was passed through $1 \mathrm{~g}$ resin column equilibrated at the same $\mathrm{pH}$. Only $\mathrm{AuCl}_{4}^{-}$was retained on the resin by ion exchange. It was partially eluted with water (5 $\mathrm{ml})$ and finally with $1 M \mathrm{KCN}(12 \mathrm{ml}, 6$ bed volumes). The effluent solution containing $\mathrm{Pd}(\mathrm{II})$ and $\mathrm{Pt}(\mathrm{IV})$, after neutralization to $\mathrm{pH}$ 6 , was percolated into a second column their separation being accomplished according to the conditions in the paragraph above.

An alternative separation procedure, start- ing from a mixture of the three metal chloride anions at $\mathrm{pH} 6$, was also developed. In this case, $\mathrm{Au}(\mathrm{III})$ and $\mathrm{Pd}(\mathrm{II})$ were quantitatively retained on the column while $\mathrm{Pt}(\mathrm{IV})$ was not. Then $\mathrm{Pd}(\mathrm{II})$ was selectively eluted with $2 M$ $\mathrm{HCl}$ while $\mathrm{Au}(\mathrm{III})$ was completely retained on the resin by anion exchange. Finally, $\mathrm{Au}(\mathrm{III})$ was eluted with water and $1 \mathrm{M} \mathrm{KCN}$.

\section{CONCLUSIONS}

The resin allows a selective separation of $\mathrm{Pd}(\mathrm{II})$ from $\mathrm{Pt}(\mathrm{II})$ or $\mathrm{Pt}(\mathrm{IV})$ in aqueous chloride solutions at $\mathrm{pH} 6$ because of very different kinetics of complexation. In hydrochloric acid media $(\mathrm{pH} \leqslant 0) \mathrm{Au}(\mathrm{III})$ can be separated

TABLE 3

Separation of mixtures containing $\mathrm{Pd}(\mathrm{II}) / \mathrm{Pt}(\mathrm{IV}) / \mathrm{Au}(\mathrm{III})$ by the resin at $\mathrm{pH} 0$ and 6

\begin{tabular}{|c|c|c|c|c|c|c|c|c|c|}
\hline \multirow[t]{2}{*}{$\mathrm{pH}$} & \multicolumn{3}{|c|}{$\begin{array}{l}\text { Initial concn. } \\
\text { in } 20 \mathrm{ml}(\mathrm{mg})\end{array}$} & \multicolumn{3}{|c|}{$\begin{array}{l}\text { Effluent concn. } \\
\text { in } 25 \mathrm{ml}(\mathrm{mg})\end{array}$} & \multicolumn{3}{|c|}{$\begin{array}{l}\text { Eluate concn. in } 25 \\
\mathrm{ml}(\mathrm{mg})^{a, b}\end{array}$} \\
\hline & $\mathrm{Pd}$ & $\mathrm{Pt}$ & $\mathrm{Au}$ & $\mathrm{Pd}$ & $\mathrm{Pt}$ & $\overline{\mathrm{Au}}$ & $\overline{P d}$ & $\mathrm{Pt}$ & $\mathrm{Au}$ \\
\hline 0 & 11.46 & 8.11 & 11.0 & 11.46 & 8.11 & 0 & 0 & 0 & $11.0^{b}$ \\
\hline $6^{c}$ & 10.98 & 9.6 & 10.5 & 0 & 9.6 & 0 & $10.98^{\text {A }}$ & 0 & $10.5^{\mathrm{b}}$ \\
\hline
\end{tabular}

Conditions: $1 \mathrm{~g}$ resin, bed volume $2 \mathrm{ml}$; flow rate $8 \mathrm{ml} \mathrm{h}^{-1} ;{ }^{\mathrm{a}} 2 \mathrm{M} \mathrm{HCl} ;{ }^{\mathrm{b}} 1 \mathrm{M} \mathrm{KCN}$; eluent volume for $100 \%$ recovery of $\mathrm{Pd}(\mathrm{II})$ or $\mathrm{Au}(\mathrm{III})=12 \mathrm{ml}(2 \mathrm{M} \mathrm{HCl}$ or $1 \mathrm{M} \mathrm{KCN}) ;{ }^{\mathrm{c}} \mu=1 \mathrm{~mol} / 1 \mathrm{KCl}$ (initial solutions). 
from $\mathrm{Pd}(\mathrm{II})$ and/or $\mathrm{Pt}(\mathrm{IV})$ by anion exchange. The elution contitions $(2 \mathrm{M} \mathrm{HCl}, 1$ $M \mathrm{KCN}$ ) do not compromise the stability of the resin. The saturation sorption capacities at $\mathrm{pH} 6(0.89 \mathrm{mmol} \mathrm{Au}$ and $0.84 \mathrm{mmol} \mathrm{Pd} / \mathrm{g}$ dry resin) correspond to about $60 \%$ of the theoretical capacity $(1.49 \mathrm{mmol} / \mathrm{g}$ based on elemental analysis); this may indicate that some chelating groups are not available for chelation because they are placed in a less favourable microenvironment for metal ion solution.

\section{ACKNOWLEDGEMENTS}

We thank the Italian Ministry of Education and CNR (Rome) for financial support and Miss Tatiana Bobbo for technical assistance.

\section{REFERENCES}

1 A. Warshawsky, Selective ion exchange polymers, Angew. Macromol. Chem., 109/110 (1982) 171.

2 S.K. Sahni and J. Reedijk, Coordination chemistry of chelating resins and ion exchangers, Coord. Chem. Rev., 59 (1984) 1, and references therein.

3 Bio-Rad Laboratories, Separating Metals Using Chelex-100 Chelating Resin, Product Information 2020, March, 1981.

4 M. Marhol, Ion Exchangers in Analytical Chemistry. Their Properties and Use in Inorganic Chemistry, in: G. Svehla (Ed.), Comprehensive Analytical Chemistry, Vol. XIV, Elsevier, Amsterdam, 1982.

5 X.-Y. Zhou and N.M. Kostic, Cuncurrent and reversible changes of color and of phase in an acque- ous solution of the (2,6-pyridinedicarboxylato)chloroplatinate(II) complex. Spectroscopic and crystallographic studies of the discrete monomer and evidence of a stacked polymer, Inorg. Chem., 27 (1989) 4402.

6 L. Cattalini, G. Chessa, G. Marangoni, B. Pitteri and E. Celon, Synthesis and characterization of anionic platinum(II) complexes containing the tridentate ligand pyridine-2,6-dicarboxylato, (O-N-O), and the kinetics of chloride displacement from [Pt(O-N-O)Cl] , Inorg. Chem., 28 (1989) 1944.

7 G. Chessa, G. Marangoni and B. Pitteri, unpublished results.

8 G. Chessa, G. Marangoni and B. Pitteri, Cross-linked polystyrene resins with 2,6-diformylpyridine bis( $2^{\prime}$-pyridylhydrazone) groups. Syntheses and metal ion chelation properties, Reactive Polym., 12 (1990) 219.

9 R.M. Diamond, The aqueous solution behaviour of large univalent ions. A new type of ion-pairing, J. Phys. Chem., 67 (1963) 2513.

10 G. Annibale, L. Canovese, L. Cattalini, G. Marangoni G. Michelon and M.L. Tobe, Displacement by chloride of pyridine-2-carboxylate from dichloro (pyridine-2-carboxylato)gold(III) in acidic solution; the position of the ring opening, J. Chem. Soc. Dalton Trans., (1984) 1641.

11 J.R. Parrish and R. Stevenson, Chelating resins from 8-hydroxyquinoline, Anal. Chim. Acta, 70 (1974) 189.

12 C. Moberg, M. Weber, K. Hogberg, M. Muhammed and A.C. Nilsson, Preparation and properties of chelating ion exchangers with quinaldic acids as complexing groups. Influence of the structure on the coordinating ligands on the complexing properties, Reactive Polymers, 12 (1990) 31.

13 S. Siddhanta and H.R. Das, Separation and concentration of some platinum metal ions with a new chelating resin containing thiosemicarbazide as functional group, Talanta, 32 (1985) 457. 